\title{
Pengaruh Disiplin dan Kemandirian Belajar terhadap Hasil Belajar Matematika Siswa Kelas V Sekolah Dasar
}

\author{
Yuniatun Dwi Nurriskah, Joharman, Ratna Hidayah
}

Universitas Sebelas Maret

yuniatundn@gmail.com

\section{Article History \\ accepted 01/06/2020}

\begin{abstract}
The study aimed to prove the positive effect of: (1) learning discipline on mathematics learning outcomes; (2) independence in learning on mathematics learning outcomes; (3) discipline and independence in learning on mathematics learning outcomes. The study used correlational method. The population was 34 students in of fifth grade students of public elementary schools in Klirong sub-district in academic year of 2019/2020 and the sample was 220 students from 11 elementary schools was taken by random sampling technique. Data analysis used multiple regression analysis with a significance level of 5\%. First research results, there is a positive but not significant effect between learning discipline and mathematics learning outcomes of fifth grade students with tcount $=0.977<$ ttable $=1.652$. The effective contribution of learning discipline to mathematics learning outcomes is $2.09 \%$. Second, there is a positive and significant effect between learning independence and mathematics learning outcomes outcomes of fifth grade students with tcount $=5,013>$ ttable $=1,652$. The effective contribution of learning independence to mathematics learning outcomes is $15.35 \%$. Third, there is a positive and significant effect between learning discipline and independence with mathematics learning outcomes outcomes of fifth grade students with Fcount $=24.559>$ Ftable $=3.037$. The effective contribution of discipline and independence of learning to mathematics learning outcomes is $17.44 \%$. The regression equation obtained is $Y=-9,367+0.013 X_{1}+0.075 X_{2}$.
\end{abstract}

Keywords: learning discipline, independence in learning, mathematics

\section{Abstrak}

Penelitian ini bertujuan untuk mengetahui ada tidaknya pengaruh positif (1) disiplin belajar terhadap hasil belajar matematika; (2) kemandirian belajar terhadap hasil belajar matematika; (3) disiplin dan kemandirian belajar terhadap hasil belajar matematika. Penelitian ini menggunakan metode korelasional. Populasi adalah siswa kelas V SDN Se-Kecamatan Klirong sejumlah 34 SD dan diambil sampel 220 siswa dari 11 SD dengan teknik random sampling. Analisis data menggunakan analisis regresi ganda dengan taraf signifikansi $5 \%$. Hasil penelitian Pertama, terdapat pengaruh positif tetapi tidak signifikan antara disiplin belajar dengan hasil belajar matematika siswa kelas $V$ dengan thitung $=0,977<$ ttabel $=1,652$. Sumbangan efektif disiplin belajar terhadap hasil belajar matematika sebesar 2,09\%. Kedua, terdapat pengaruh positif dan signifikan antara kemandirian belajar dengan hasil belajar matematika siswa kelas $\mathrm{V}$ dengan thitung $=5,013>$ ttabel $=1,652$. Sumbangan efektif kemandirian belajar terhadap hasil belajar matematika sebesar $15,35 \%$. Ketiga, terdapat pengaruh positif dan signifikan antara disiplin dan kemandirian belajar dengan hasil belajar matematika siswa kelas $\mathrm{V}$ dengan Fhitung $=24,559>\mathrm{Ftabel}=3,037$. Sumbangan efektif disiplin dan kemandirian belajar terhadap hasil belajar matematika yaitu $17,44 \%$. Persamaan regresi yang diperoleh yaitu $Y=-9,367+$ $0,013 \times 1+0,075 X 2$.

Kata kunci: disiplin belajar, kemandirian belajar, matematika 


\section{PENDAHULUAN}

Matematika merupakan salah satu muatan pelajaran yang sangat erat kaitannya dalam kehidupan sehari-hari, oleh karena itu siswa diharapkan mampu menguasainya dengan baik. Menurut Susanto (2016) matematika dapat meningkatkan kemampuan berpikir kritis dan bernalar, memberikan sumbangan dalam pemecahan masalah sehari-hari dan dalam dunia kerja, serta mendukung pengembangan iptek. Hal ini menunjukkan bahwa matematika sangat penting dalam kehidupan. Namun pada kenyataan yang ada, penguasaan matematika masih menjadi suatu permasalahan yang besar. Berdasarkan hasil nilai PAS Matematika kelas V semester I tahun 2019/2020 di SDN 1 Kedungsari, terdapat 13 dari 24 siswa (54,16\%) yang belum mencapai nilai KKM yaitu 68.

Hasil belajar adalah pencapaian bentuk perilaku yang baru serta cenderung menetap dari ranah kognitif, afektif, dan psikomotor dari proses belajar yang dilakukan dalam waktu tertentu terhadap suatu muatan pelajaran. Ranah kognitif menjadi landasan bagi penguasaan ilmu pengetahuan dan terdiri dari tiga kemampuan yang harus dikuasai yaitu persepsi, mengingat, dan berpikir (Djamarah, 2015).

Matematika adalah salah satu muatan pelajaran yang membutuhkan pemikiran tingkat tinggi. Matematika yaitu bahan kajian yang objeknya abstrak dan dibangun melalui proses penalaran deduktif, mempunyai bahasa dan aturan yang terdefinisi baik, penalaran yang sistematis, dan keterkaitan antarkonsep yang kuat. (Wahyudi, 2015; Susanto, 2016). Hasil belajar matematika adalah pencapaian bentuk perilaku yang baru serta cenderung menetap dari ranah kognitif, afektif, dan psikomotor dari proses belajar matematika yang ditunjukkan dengan skor atau angka. Penelitian ini fokus pada hasil belajar siswa kelas V SD pada aspek kognitif dengan kompetensi dasar matematika semester I (ganjil).

Ada beberapa faktor yang memengaruhi hasil belajar matematika. Sobur (2016) mengungkapkan faktor yang memengaruhi hasil belajar yaitu faktor endogen dan faktor eksogen. Dari berbagai hasil penelitian yang disimpulkan oleh Aunurrahman (2019: 111) menyatakan bahwa keberhasilan belajar ternyata lebih banyak ditentukan oleh faktor-faktor emosi, antara lain daya tahan, keuletan, ketelitian, disiplin, tanggung jawab, kerjasama, motivasi, serta beberapa dimensi emosional lainnya. Di dalam faktor endogen yang memengaruhi hasil belajar terdapat faktor fisik dan psikis, di dalam faktor psikis terdapat faktor motivasi (Sobur, 2016). Menurut Sardiman (2018) salah satu ciri orang yang memiliki motivasi adalah lebih senang bekerja mandiri. Artinya adanya kemandirian dalam belajar memungkinkan dapat memengaruhi hasil belajar seseorang. Hal ini menimbulkan dugaan bahwa disiplin dan kemandirian belajar mampu memengaruhi hasil belajar.

Kedisiplinan di sekolah erat kaitannya dengan kerajinan siswa dalam belajar (Slameto, 2013). Hal ini memperkuat dugaan bahwa disiplin sangat penting dalam proses belajar siswa. Namun dari hasil observasi menunjukkan siswa belum mengerti pentingnya disiplin belajar ditunjukkan dengan siswa banyak yang bermain di kelas saat pembelajaran. Selain itu berdasarkan wawancara dengan guru kelas $\mathrm{V}$ yang dilakukan di SDN 3 Kedungsari pada 23 November 2019, didapatkan informasi diantaranya: (1) Siswa cenderung kurang menguasai pembelajaran matematika; (2) siswa banyak yang bermain di kelas, (3) siswa terlambat masuk kelas setelah waktu istirahat; (4) sebagian siswa tidak belajar di rumah, dan (5) siswa kurang termotivasi belajar matematika.

Disiplin adalah salah satu sikap yang dikembangkan dalam proses pendidikan. Tu'u mengemukakan bahwa disiplin adalah pernyataan sikap mental individu maupun masyarakat yang menggambarkan rasa ketaatan, kepatuhan yang didukung oleh kesadaran untuk menunaikan tugas dan kewajiban dalam rangka pencapaian tujuan (Asrah, Novita, \& Fitriati, 2016), sedangkan belajar adalah sebagai suatu kegiatan yang ditunjukkan oleh perubahan tingkah laku sebagai hasil dari pengalaman 
(Cronbach dalam Djamarah, 2015: 13; Sobur, 2016). Menurut Kompri (2014) disiplin ialah suatu tata tertib yang dapat mengatur tatanan kehidupan belajar. Dewi, Suwatra, \& Suwarjana (2019) mengatakan bahwa disiplin belajar merupakan teknik atau cara belajar yang dilakukan sesuai dengan aturan yang berlaku.

Disiplin dapat diukur atau dapat diobservasi baik secara emosional maupun tampilan perilaku (Daryanto \& Darmiatun, 2013). Tu"u (Rahartiwi, 2016) mengemukakan indikator yang menunjukkan perubahan hasil belajar siswa sebagai sumbangan dari mengikuti dan menaati peraturan sekolah. Indikator tersebut meliputi: (1) dapat mengatur waktu belajar di rumah, (2) rajin dan teratur belajar, (3) perhatian yang baik saat belajar, (4) ketertiban diri saat belajar. Menurut Sulistiyowati (Elly, 2016), siswa yang mempunyai disiplin belajar memiliki ciri-ciri sebagai berikut: (1) disiplin dalam mencapai jadwal belajar; (2) disiplin tidak menunda-nunda waktu belajar; (3) disiplin terhadap diri sendiri untuk semangat belajar baik di sekolah maupun disiplin di rumah; dan (4) disiplin dalam menjaga kondisi fisik agar selalu sehat.

Berdasarkan tingkat kelasnya, Daryanto \& Darmiatun (2013) menyatakan indikator nilai disiplin untuk SD kelas 4-6 meliputi: (1) menyelesaikan tugas pada waktunya, (2) saling menjaga dengan teman agar semua tugas-tugas kelas terlaksana dengan baik, (3) selalu mengajak teman menjaga ketertiban kelas, (4) mengingatkan teman yang melanggar peraturan dengan kata-kata sopan dan tidak menyinggung, (5) berpakaian sopan dan rapi, dan (6) mematuhi aturan sekolah.

Berdasarkan penjelasan di atas, indikator yang menunjukkan adaya disiplin belajar meliputi: (1) dapat mengatur waktu belajar di rumah; (2) rajin dan teratur belajar; (3) perhatian yang baik saat belajar; (4) ketertiban diri saat belajar; (5) mengajak teman menjaga ketertiban kelas; dan (6) mematuhi aturan sekolah.

Kemandirian ialah usaha untuk mengatur pikiran, perasaan, dan tindakan sendiri secara bebas serta berusaha sendiri untuk mengatasi perasaan malu dan bimbang (Desmita, 2017: 185). Sikap ini sangat penting dimiliki oleh siswa dalam proses pembelajaran. Namun fakta yang terjadi di lapangan adalah siswa yang kurang mandiri dalam belajar ditandai dengan kurang inisiatif siswa dalam mengerjakan tugas yang diberikan guru serta siswa cenderung bergantung pada guru. Hal ini diperkuat dengan hasil wawancara dengan guru kelas V SD N 1 Kedungsari pada 25 November 2019, diantaranya: (1) siswa kurang inisiatif, (2) masih tergantung dengan guru; (3) sebagian masih kurang bersikap bertanggung jawab; (4) siswa kurang mampu bekerja sendiri; dan (5) sebagian siswa kurang bisa membuat keputusan sendiri.

Mandiri adalah suatu nilai dalam pendidikan budaya dan karakter bangsa. Kemandirian dalam proses belajar memiliki makna lebih sempit. Menurut Mujiman (Nurhayati, 2016) menyatakan bahwa kemandirian belajar adalah kegiatan belajar aktif yang didorong oleh motif untuk menguasai suatu kompetensi guna mengatasi suatu masalah, dibangun dengan bekal pengetahuan atau kompetensi yang dimiliki, baik dalam menetapkan waktu belajar, tempat belajar, tempo belajar, cara belajar, maupun evaluasi belajar yang dilakukan oleh pembelajar sendiri.

Seorang pembelajar dapat diketahui kemandirian belajarnya melalui beberapa indikator kemandirian belajar. Menurut Hiemstra (Nurhayati, 2016), karakteristik pembelajar yang mandiri yaitu: (1) hubungan antara guru dan pembelajar tetap ada, tetapi bukan hubungan ketergantungan; (2) mengetahui kapan membutuhkan bantuan dan harus minta tolong; (3) mengetahui kepada siapa dan darimana memperoleh bantuan. (4) mengetahui kapan perlu menggunakan media belajar, (5) mengetahui cara mempergunakan media belajar, dan (6) mengetahui berbagai berbagai strategi belajar yang efektif. Desmita (2017) menyatakan bahwa kemandirian biasanya ditandai dengan kemampuan menentukan nasib sendiri, kreatif dan inisiatif, mengatur tingkah laku, bertanggung jawab, mampu menahan diri, membuat keputusan sendiri, serta mampu mengatasi masalah tanpa ada pengaruh dari orang lain 
Masrun, dkk (Sa'diyah, 2017) menyatakan indikator seseorang dapat dikatakan mandiri apabila memenuhi lima komponen sebagai berikut: (1) bebas, artinya dalam bertindak tidak tergantung orang lain; (2) progresif, bekerja keras untuk mengejar prestasi, tekun dan memiliki rencana dalam mewujudkan harapannya; (3) inisiatif, artinya dalam bertindak merupakan hasil pemikiran sendiri; (4) terkendali, artinya mampu memecahkan masalah yang dihadapi, mampu mengendalikan tindakan, serta mampu memengaruhi lingkungan atas usaha sendiri; dan (5) kemantapan diri, artinya memiliki rasa percaya diri dan harga diri yang tinggi terhadap kemampuan, dan usahanya sendiri. Berdasarkan penjelasan di atas, indikator yang menunjukkan adanya kemandirian belajar matematika meliputi: (1) inisiatif dengan tidak bergantung pada guru, (2) bertanggung jawab (3) progresif, (4) mampu bekerja sendiri, (5) mampu membuat keputusan sendiri, (6) percaya diri.

Berdasarkan uraian tersebut, peneliti bermaksud untuk melakukan penelitian untuk membuktikan ada atau tidaknya (1) pengaruh positif disiplin belajar dengan hasil belajar matematika; (2) pengaruh positif kemandirian belajar dengan hasil belajar matematika; (3) pengaruh positif disiplin dan kemandirian belajar dengan hasil belajar matematika siswa kelas V SDN se-Kecamatan Klirong Tahun Ajaran 2019/2020.

\section{METODE}

Penelitian ini menggunakan desain penelitian kuantitatif korelasi menggunakan analisis regresi berganda. Penelitian korelasi adalah penelitian yang melibatkan hubungan satu atau lebih variabel dengan satu atau lebih variabel lain (Purwanto, 2012). Menurut Winarsunu (2017) anareg dua prediktor ialah suatu teknik statistik parametrik untuk menguji pertautan 2 prediktor $\left(X_{1}\right.$ dan $\left.X_{2}\right)$ dengan variabel kriterium $(Y)$. Analisis regresi berganda dilakukan dengan menguji pengaruh variabel terikat yaitu hasil belajar matematika kelas $\mathrm{V}$ terhadap variabel bebas yang yaitu disiplin belajar dan kemandirian belajar. Selanjutnya dilakukan perhitungan sumbangan efektif. Populasi penelitian ini adalah siswa kelas V SDN Se-Kecamatan Klirong sejumlah 34 SD dan diambil sampel 220 siswa dari 11 SD dengan teknik random sampling. Aspek yang dikembangkan untuk mengukur hasil belajar matematika yaitu kompetensi dasar 3.1, 3.2, 3.3, dan 3.4. Aspek yang dikembangkan dalam angket disiplin belajar yaitu (1) dapat mengatur waktu belajar di rumah; (2) rajin dan teratur belajar; (3) perhatian yang baik saat belajar; (4) ketertiban diri saat belajar; (5) mengajak teman menjaga ketertiban kelas; dan (6) mematuhi aturan sekolah. Aspek yang dikembangkan dalam angket kemandirian belajar yaitu (1) inisiatif dengan tidak bergantung pada guru, (2) bertanggung jawab (3) progresif, (4) mampu bekerja sendiri, (5) mampu membuat keputusan sendiri, (6) percaya diri.

Sumber data diperoleh dari sampel yang diambil dengan teknik random sampling atau pengambilan sampel secara acak. Jumlah populasi sebesar 870 siswa dari 34 sekolah dan diambil sampel sejumlah 275 dari 11 SD, namun sampel diperkecil menjadi 220 siswa dikarenakan pertimbangan kondisi yang tidak memungkinkan. Hal ini mengacu pada teori ukuran sampel minimum yang harus diambil dari suatu populasi. Menurut Gay, Mills dan Airasian (2009) untuk penelitian metode deskriptif, minimal $10 \%$ populasi, untuk populasi yang relatif kecil minimal $20 \%$, sedangkan untuk penelitian korelasi diperlukan sampel sebesar 30 responden (Alwi, 2015).

Teknik pengumpulan data yang digunakan dalam penelitian ini yaitu angket dan tes. Angket digunakan untuk mengumpulkan data penelitian pada variabel disiplin dan kemandirian belajar dengan skala likert, sedangkan tes digunakan untuk mengumpulkan data penelitian pada variabel hasil belajar matematika. Jenis data variabel $X_{1}$ dan $X_{2}$ pada penelitian ini adalah data ordinal, sedangkan jenis data variabel $Y$ adalah data interval. Agar data dapat dianalisis maka peneliti harus meningkatkan tingkat pengukuran ordinal (data angket) menjadi interval menggunakan metode succesive interval (MSI). Uji persyaratan analisis data pada penelitian ini yaitu 
uji normalitas, uji linearitas, dan uji multikolinearitas. Selanjutnya uji analisis data dilakukan dengan analisis regresi sederhana dan analisis regresi berganda menggunakan IBM SPSS Statistics 25.

\section{Deskripsi Data}

\section{HASIL DAN PEMBAHASAN}

Sebelum dianalisis, jenis data ordinal (data angket) diubah menjadi data interval dengan metode MSI. Data dapat disajikan dalam tabel 1.

\begin{tabular}{|c|c|c|c|c|c|c|c|c|c|}
\hline \multirow[b]{2}{*}{ Kelas } & \multicolumn{3}{|c|}{ Hasil Belajar } & \multicolumn{3}{|c|}{ Disiplin Belajar } & \multicolumn{3}{|c|}{ Kemandirian Belajar } \\
\hline & \multicolumn{2}{|c|}{ Interval } & \multirow{2}{*}{$\frac{\text { Frekuensi }}{13}$} & \multicolumn{2}{|c|}{ Interval } & \multirow{2}{*}{$\frac{\text { Frekuensi }}{22}$} & \multicolumn{2}{|c|}{ Interval } & \multirow{2}{*}{$\frac{\text { Frekuensi }}{15}$} \\
\hline 1 & 2 & $\begin{array}{l}-5 \\
-\quad 5\end{array}$ & & 212 & -230 & & 216 & -240 & \\
\hline 2 & 6 & -9 & 27 & 231 & - 249 & 14 & 241 & -265 & 26 \\
\hline 3 & 10 & -13 & 32 & 250 & -268 & 32 & 266 & -290 & 41 \\
\hline 4 & 14 & -17 & 39 & 269 & - $\quad 287$ & 41 & 291 & - 315 & 61 \\
\hline 5 & 18 & -21 & 46 & 288 & - 306 & 46 & 316 & -340 & 50 \\
\hline 6 & 22 & -25 & 31 & 307 & $-\quad 325$ & 32 & 341 & -365 & 18 \\
\hline 7 & 26 & -29 & 27 & 326 & - 344 & 11 & 366 & - 390 & 9 \\
\hline 8 & 30 & -33 & 5 & 345 & - 363 & 14 & 391 & - 415 & 0 \\
\hline \multirow[t]{2}{*}{9} & 34 & $\begin{array}{l}-\quad 37 \\
\end{array}$ & 0 & 364 & $-\quad 382$ & 8 & 416 & $-\quad 440$ & 0 \\
\hline & Tot & & 220 & & & 220 & & & 220 \\
\hline
\end{tabular}

Semua data berasal dari 220 sampel penelitian. Skor hasil belajar matematika diungkap menggunakan tes dengan bentuk pilihan ganda sebanyak 30 item. Hasil tes hasil belajar matematika menunjukan skor tertinggi 30 , skor terendah 2 , mean 16,98, modus 18 , median 70 , standar deviasi 7,130, dan varians 51,324.

Skor disiplin belajar diperoleh dari angket minat baca dengan jumlah pertanyaan 49. Dari sebaran angket diperoleh nilai tertinggi 381,246 dan terendah 196,546. Sedangkan mean 286,71124, modus 281,952, median 287,253, standar deviasi 40,142703 dan varians 1611,437 .

Skor kemandirian belajar diperoleh dari angket minat baca dengan jumlah pertanyaan 40. Dari sebaran angket diperoleh nilai tertinggi 386,296 dan terendah 209,485 . Sedangkan mean 299,43109, modus 285,187, median 300,72300 , standar deviasi 36,288303 dan varians 1316,841 .

\section{Uji Persyaratan Analisis}

Uji persyaratan pada penelitian ini ada tiga macam yaitu uji normalitas, uji linearitas, dan uji multikolinearitas. Analisis uji normalitas menggunakan uji liliefors Kolmogorov-Smirnorv dengan hasil nilai Asymp. Sig. (2-tailed) pada ketiga variabel yaitu 0,200 sehingga dapat diketahui bahwa signifikansi $>0,05$. Oleh karena itu, dapat disimpulkan bahwa terima $\mathrm{Ho}$ atau variabel disiplin belajar, kemandirian belajar, dan hasil belajar matematika berasal dari populasi yang berdistribusi normal.

Tabel 1. Rangkuman Hasil Uji Linearitas

\begin{tabular}{lllc}
\hline \multicolumn{1}{c}{ Variabel } & Fhitung & Sig. & Keterangan \\
\hline Hasil BelajarDisiplin & 2,220 &, 187 & Linear \\
Hasil Belajar* Kemandirian & 3,389 &, 412 & Linear \\
\hline
\end{tabular}

Berdasarkan uji linearitas pada tabel 1, dapat diketahui bahwa pada uji linearitas variabel hasil belajar matematika dan disiplin belajar didapatkan signifikansinya $0,187>0,05$ sehingga dapat disimpulkan bahwa terdapat hubungan linear antara hasil belajar matematika dan variabel disiplin belajar. Hasil uji linearitas variabel hasil belajar 
matematika dan kemandirian belajar diperoleh signifikansi $0,412>0,05$ sehingga dapat disimpulkan bahwa terdapat hubungan linear antara hasil belajar matematika dan variabel kemandirian belajar.

Tabel 2. Rangkuman Hasil Uji Multikolinearitas

\begin{tabular}{lrrr}
\hline \multirow{2}{*}{ Model } & \multicolumn{2}{c}{ Collinearity Statistics } & \multirow{2}{*}{ Keterangan } \\
\cline { 2 - 3 } & Tolerance & VIF & \\
\hline Disiplin belajar &, 649 & 1,540 & Tidak terjadi multikolinieritas \\
Kemandirian belajar &, 649 & 1,540 & Tidak terjadi multikolinieritas \\
\hline
\end{tabular}

Dari tabel 4 terlihat seriap variabel bebas memiliki nilai tolerance 0,649 dan nilai VIF 1,540. Dapat disimpulkan tidak terjadi multikolinearitas dalam variabel disiplin belajar dan kemandirian belajar pada model regresi linear berganda karena nilai tolerance $<0,10$ serta nilai $\mathrm{VIF}<10$.

\section{Uji Hipotesis}

Pengujian hipotesis dalam penelitian ini dilakukan dengan menggunakan teknik regresi linear berganda. Dengan bantuan IBM SPSS Statistics 25 diperoleh rangkuman hasil analisis regresi sederhana pada tabel 3.

Tabel 3. Rangkuman Hasil Analisis Regresi Linear Berganda

\begin{tabular}{llll}
\hline \multicolumn{1}{c}{ Model } & Koefisien Regresi (B) & \multicolumn{1}{c}{$\mathrm{t}$} & Sig. \\
\hline Konstanta & $-9,367$ & $-2,432$ &, 016 \\
Disiplin &, 013 &, 977 &, 330 \\
Kemandirian &, 075 & 5,013 &, 000 \\
\hline Fhitung & 24,559 & & \\
Sig. F &, $000^{\mathrm{b}}$ & \\
R &, $430^{\mathrm{a}}$ & & \\
R Square & 0,185 & & \\
\hline
\end{tabular}

Berdasarkan tabel 3 di atas, persamaan regresi ganda yang diperoleh yaitu $Y=-$ $9,367+0,013 X_{1}+0,075 X_{2}$. Dari persamaan regresi tersebut dapat dijelaskan konstanta $-9,367$ berarti jika disiplin belajar $(X 1)$ dan kemandirian belajar $(X 2)=0$, maka hasil belajar matematika $(Y)$ nilainya $-9,367$. Koefisien regresi variabel disiplin belajar (X1) sebesar 0,013, artinya jika disiplin belajar mengalami kenaikan sebesar 0,013 , maka hasil belajarnya mengalami peningkatan sebesar 0,013 dengan asumsi variabel independen lain bernilai tetap. Tanda koefisien korelasi positif $(+)$ menyatakan arah hubungan yang searah dimana kenaikan atau penurunan variabel $X$ akan mengakibatkan kenaikan atau penurunan variabel $\mathrm{Y}$. Koefisien bernilai positif artinya terjadi hubungan yang positif antara disiplin belajar dan hasil belajar matematika.

Koefisien regresi variabel kemandirian belajar (X2) sebesar 0,075, artinya jika disiplin belajar mengalami kenaikan sebesar 0,075, maka hasil belajarnya mengalami peningkatan sebesar 0,075 dengan asumsi variabel independen lain bernilai tetap. Tanda koefisien korelasi positif $(+)$ menyatakan arah hubungan yang searah dimana kenaikan atau penurunan variabel $X$ akan mengakibatkan kenaikan atau penurunan variabel $\mathrm{Y}$. Koefisien bernilai positif artinya terjadi hubungan yang positif antara kemandirian belajar dan hasil belajar matematika.

Berdasarkan kolom t pada tabel 3 hasil perhitungan analisis regresi linier untuk variabel $\mathrm{X} 1$ diketahui bahwa nilai thitung $=0,977$ sedangkan ttabel dengan taraf kesalahan $5 \%$ dan $\mathrm{df}=\mathrm{N}-2=220-2=218$ diperoleh nilai sebesar 1,652. Dengan demikian nilai 0,977 < 1,652 atau thitung < ttabel, maka Ho diterima. Nilai signifikansi yang diperoleh yaitu 0,330 . Karena nilai signifikansi lebih kecil dari 0,05 maka dapat disimpulkan bahwa Ho1 ditolak. Jadi dapat disimpulkan bahwa disiplin belajar tidak berpengaruh signifikan terhadap hasil belajar matematika siswa kelas V SDN seKecamatan Klirong tahun ajaran 2019/2020. 
Berdasarkan kolom t pada tabel 3 hasil perhitungan analisis regresi linier untuk variabel X2 berdasarkan kolom t pada tabel Coefficients diketahui bahwa nilai thitung $=5,013$ sedangkan ttabel dengan taraf kesalahan $5 \%$ dan df $=\mathrm{N}-2=220-2=218$ diperoleh nilai sebesar 1,652. Dengan demikian nilai 5,013 >1,652 atau thitung > ttabel, maka Ho ditolak. Nilai signifikansi yang diperoleh yaitu 0,000 . Karena nilai signifikansi lebih kecil dari 0,05 maka dapat disimpulkan bahwa Ho1 ditolak. Jadi dapat disimpulkan bahwa kemandirian belajar berpengaruh signifikan terhadap hasil belajar matematika siswa kelas V SDN se-Kecamatan Klirong tahun ajaran 2019/2020.

Dari tabel 3 diketahui bahwa nilai $F_{\text {hitung }}=24,559$ sedangkan $F_{\text {tabel }}$ dengan taraf kesalahan $5 \%$ dan df $=\mathrm{N}-2=220-2=218$ diperoleh nilai sebesar 3,037. Dengan demikian nilai 24,559 $>3,037$ atau $F_{\text {hitung }}>F_{\text {tabel. }}$. Nilai signifikansi yang diperoleh yaitu $0,000<0,05$ maka dapat disimpulkan bahwa terdapat pengaruh positif disiplin dan kemandirian belajar secara bersama-sama terhadap hasil belajar matematika siswa kelas V SDN se-Kecamatan Klirong tahun ajaran 2019/2020.

Sumbangan efektif adalah ukuran sumbangan pengaruh variabel $X$ (disiplin dan kemandirian belajar) terhadap seberapa besar nilai variabel $Y$ (hasil belajar matematika siswa kelas V). Pada analisis sumbangan relatif dan koefisien determinasi, penelitian menggunakan aplikasi IBM SPSS Statistics 25 untuk mencari nilai $\mathrm{R}^{2}$, nilai b, dan nilai JKreg. Sedangkan untuk mencari jumlah $x_{1} y$ dan $x_{2} y$ peneliti menggunakan bantuan Ms. Excell 2016.

Tabel 4. Hasil Analisis Koefisien Determinasi

Model Summary

\begin{tabular}{lcccc}
\hline Model & $\mathrm{R}$ & $\begin{array}{c}\mathrm{R} \\
\text { Square }\end{array}$ & $\begin{array}{c}\text { Adjusted } \mathrm{R} \\
\text { Square }\end{array}$ & $\begin{array}{c}\text { Std. Error of the } \\
\text { Estimate }\end{array}$ \\
\hline 1 &, $430^{\mathrm{a}}$ &, 185 &, 177 & 6,499
\end{tabular}

a. Predictors: (Constant), Kemandirian, Disiplin

Tabel 5. Hasil Uji Regresi Linear Berganda

ANOVA $^{a}$

\begin{tabular}{|c|c|c|c|c|c|c|}
\hline \multicolumn{2}{|c|}{ Model } & Sum of Squares & $\mathrm{df}$ & Mean Square & $\mathrm{F}$ & Sig. \\
\hline 1 & & 2074,607 & 2 & 1037,304 & 24,559 &, $000^{\mathrm{b}}$ \\
\hline & $\begin{array}{l}\text { Regression } \\
\text { Residual }\end{array}$ & 9165,320 & 217 & 42,236 & & \\
\hline & Total & 11239,927 & 219 & & & \\
\hline
\end{tabular}

a. Dependent Variable: Hasil Belajar

b. Predictors: (Constant), Kemandirian, Disiplin

Berdasarkan tabel 4 di atas, nilai koefisien korelasi $R$ sebesar 0,430 , nilai kuadratnya pada kolom RSquare sebesar 0,185, dan nilai Adjusted R Square sebesar 0,177 . Karena penelitian ini meneliti lebih dari satu variabel bebas maka koefisien determinasi diambil dari kolom Adjusted $R$ Square yaitu 0,177. Berdasarkan persamaan regresi $Y=-9,367+0,013 X 1+0,075 X 2$ menunjukkan nilai $b=0,013$ dan nilai $\mathrm{C}=0,075$. Pada tabel 5 menunjukkan $\mathrm{JKreg}=2074,607$. Pada perhitungan $\mathrm{xy}$ diperoleh $x 1 y=18907,319$ dan $x 2 y=24221,386$. Dari data tersebut maka sumbangan relatif (SR) dan sumbangan efektif (SE) dapat dihitung sebagai berikut.

1) Sumbangan Relatif

$$
\begin{aligned}
S R_{x 1} & =\frac{b\left(\sum x_{1} y\right)}{J k_{r e g}} \times 100 \% \\
S R \times 1 & =\frac{0,013(18907,319)}{2074,607} \times 100 \% \\
S R x 1 & =12 \%
\end{aligned}
$$$$
\begin{aligned}
& S R_{x 2}=\frac{c\left(\sum x_{2} y\right)}{J k_{r e g}} x 100 \% \\
& \text { SRx1 }=\frac{0,075(24221,386)}{2074,607} \times 100 \% \\
& \text { SRx1 }=88 \%
\end{aligned}
$$ 
2) Sumbangan Efektif

$$
\begin{array}{ll}
\text { SEx1 }=(\mathrm{SR} x 1) \times(\mathrm{R} 2) & \text { SEx2 }=(\mathrm{SR} \times 2) \times(\mathrm{R} 2) \\
\text { SEx1 }=11,8 \% \times 0,177 & \text { SEx1 }=87,6 \% \times 0,177 \\
\text { SEx1 }=2,09 \% & \text { SEx1 }=15,35 \%
\end{array}
$$

Berdasarkan hasil perhitungan di atas, maka total kontribusi variabel disiplin dan kemandirian belajar terhadap hasil belajar matematika dapat dirangkum pada tabel berikut.

Tabel 6. Sumbangan Relatif dan Sumbangan Efektif Variabel-Variabel Bebas terhadap Hasil Belajar Matematika

\begin{tabular}{lcc}
\hline \multicolumn{1}{c}{ Variabel } & Sumbangan Relatif & Sumbangan Efektif \\
\hline Disiplin Belajar & $12 \%$ & $2,09 \%$ \\
Kemandirian Belajar & $88 \%$ & $15,35 \%$ \\
\hline Jumlah & $100 \%$ & $17,44 \%$ \\
\hline
\end{tabular}

Dari tabel 6 dapat diinterpretasikan bahwa kontribusi disiplin belajar terhadap hasil belajar sebesar 2,09\% dan $97,91 \%$ hasil belajar dipengaruhiu oleh faktor lain. Sumbangan kemandirian belajar terhadap hasil belajar sebesar $15,35 \%$ dan $84,65 \%$ dipengaruhi oleh faktor lain. Besar pengaruh disiplin dan kemandirian belajar secara bersama-sama terhadap hasil belajar matematika siswa kelas V SDN se-Kecamatan Klirong tahun ajaran $2019 / 2020$ yaitu $17,44 \%$ dan $82,56 \%$ dipengaruhi oleh faktor lain yang tidak dimasukkan dalam penelitian ini. Faktor lain yang dapat memengaruhi hasil belajar matematika siswa yaitu faktor endogen lainnya seperti perhatian, minat, motivasi, gaya belajar, dan kesiapan belajar siswa, serta faktor eksogen atau faktor dari luar diri siswa.

\section{Pengaruh Disiplin Belajar terhadap Hasil Belajar Matematika}

Hasil pengujian hipotesis menunjukkan adanya pengaruh positif dengan persamaan regresi $Y=-9,367+0,013 X 1+0,075 X 2$ dan koefisien regresi variabel disiplin belajar (X1) sebesar 0,013, artinya jika disiplin belajar mengalami kenaikan sebesar 1, maka hasil belajarnya mengalami peningkatan sebesar 0,013 dengan asumsi variabel kemandirian belajar bernilai tetap. Hasil pengujian koefisien regresi (uji t) menunjukkan bahwa nilai thitung $=0,977<$ ttabel $=1,652$ dan nilai signifikansinya $0,330>0,05$ sehingga disiplin belajar tidak berpengaruh signifikan terhadap hasil belajar matematika siswa kelas V SDN se-Kecamatan Klirong tahun ajaran 2019/2020.

Hasil analisis menunjukkan sumbangan efektif variabel disiplin belajar terhadap hasil belajar matematika adalah sebesar 2,09 dan 97,91\% dipengaruhi oleh faktor lain yang tidak dimasukkan dalam penelitian ini. Faktor lain yang memengaruhi hasil belajar diantaranya faktor endogen dan eksogen. Faktor endogen terdiri dari faktor fisik (kesehatan dan cacat tubuh) dan psikis (intelegensi atau kemampuan, perhatian dan minat, bakat, motivasi, kematangan, dan kepribadian) sedangkan faktor eksogen ini meliputi faktor keluarga, faktor sekolah, dan faktor lingkungan lain (Sobur, 2016).

Kedisiplinan mencakup kepatuhan dan ketaatan individu terhadap peraturan dan norma-norma yang berlaku pada suatu tempat, termasuk lembaga pendidikan, berdasarkan kemampuan mengendalikan diri. Kedisiplinan belajar juga merujuk pada efisiensi waktu yang ditunjukkan dengan kemampuan siswa menyelesaikan tugastugas yang diberikan oleh guru dengan tepat waktu dan hasil yang baik. Adanya kedisipinan yang terbentuk pada kepribadian siswa dapat meningkatkan produktivitas belajar dan menumbuhkan kreativitas siswa sehingga siswa menjadi aktif dalam kegiatan belajar mengajar di kelas. Adanya produktivitas siswa dalam belajar sebagai wujud dari kedisiplinan diharapkan dapat meningkatkan hasil belajar siswa. Hasil penelitian ini sesuai dengan penelitian yang dilakukan oleh Ekawati (2016: 119-130) 
dengan hasil tidak terdapat pengaruh yang signifikan disiplin terhadap hasil belajar matematika siswa kelas VII SMP Pesantren Modern Datok Sulaiman Palopo yaitu nilai Sig. $=0,077>0,05$.

\section{Pengaruh Kemandirian Belajar terhadap Hasil Belajar Matematika}

Hasil pengujian hipotesis menunjukkan bahwa nilai $t_{\text {hitung }}=5,013<t_{\text {tabel }}=1,652$ dan nilai Sig. yaitu $0,000<0,05$. Artinya hipotesis kedua penelitian ini dapat diterima atau kemandirian belajar berkorelasi positif dan signifikan dengan hasil belajar matematika siswa kelas V SDN se-Kecamatan Klirong tahun ajaran 2019/2020.

Kemandirian belajar masuk dalam faktor yang memengaruhi hasil belajar matematika siswa. Hasil analisis menunjukkan menunjukkan sumbangan efektif variabel kemandirian belajar terhadap hasil belajar matematiks adalah sebesar 15,35\% dan $84,65 \%$ dipengaruhi oleh variabel lain. Faktor lain yang memengaruhi hasil belajar diantaranya faktor endogen dan eksogen. Faktor endogen terdiri dari faktor fisik (kesehatan dan cacat tubuh) dan psikis (intelegensi atau kemampuan, perhatian dan minat, bakat, motivasi, kematangan, dan kepribadian) sedangkan faktor eksogen ini meliputi faktor keluarga, faktor sekolah, dan faktor lingkungan lain (Sobur, 2016).

Pentingnya memiliki sikap mandiri dalam belajar telah dijelaskan oleh Sumarmo yang menyatakan bahwa siswa yang memiliki kemandirian belajar, akan mampu menganalisis permasalahan yang kompleks, dapat bekerja secara individu maupun bekerja sama, serta dapat mengemukakan gagasannya dengan berani (Syahputra, 2017). Kemandirian siswa dalam belajar dilakukan atas dorongan internal dari individu tanpa bergantung pada orang lain untuk menguasai kompetensi guna mengatasi suatu masalah. Dengan memiliki kemandirian belajar, siswa dapat mengerjakan tugastugasnya dengan penuh percaya diri diserta rasa tanggungjawab yang tinggi dan mampu mengatasi masalah yang muncul pada dirinya. Kemandirian berkontribusi dalam proses pembelajaran di kelas karena beberapa hal diantaranya: (a) siswa cenderung belajar lebih baik dengan pengawasannya sendiri; (b) mampu memantau, mengevaluasi, dan mengatur belajarnya secara efektif; (c) menghemat waktu dalam menyelesaikan tugas yang diberikan guru; dan (d) mengatur belajar dan waktu secara efisien.

Hasil penelitian ini sesuai dengan penelitian yang dilakukan oleh Woi \& Prihatni (2019) yang menunjukkan bahwa terdapat hubungan positif yang signifikan antara kemandirian belajar dengan hasil belajar matematika siswa kelas VII SMPN 3 Berbah tahun ajaran 2017/2018 karena nilai sig (2-tailed) 0,023<0,05.

\section{Pengaruh Disiplin dan Kemandirian Belajar terhadap Hasil Belajar Matematika}

Hasil pengujian hipotesis menunjukkan bahwa nilai $F_{\text {hitung }}=24,559<3,037$ dan nilai signifikansi yang diperoleh yaitu $0,000<0,05$. Jadi hipotesis ketiga diterima serta dapat disimpulkan bahwa terdapat pengaruh positif disiplin dan kemandirian belajar secara bersama-sama terhadap hasil belajar matematika siswa kelas V SDN seKecamatan Klirong tahun ajaran 2019/2020. Persamaan regresi yang diperoleh yaitu $Y$ $=-9,367+0,013 X_{1}+0,075 X_{2}$.

Disiplin dan kemandirian belajar masuk dalam faktor endogen yang memengaruhi hasil belajar. Hasil analisis menunjukkan sumbangan efektif variabel disiplin belajar dan kemandirian belajar terhadap hasil belajar matematiks adalah sebesar $17,44 \%$. Jadi, besar pengaruh disiplin dan kemandirian belajar secara bersama-sama terhadap hasil belajar matematika siswa kelas V SDN se-Kecamatan Klirong tahun ajaran $2019 / 2020$ yaitu $17,44 \%$ dan $82,56 \%$ dipengaruhi oleh faktor lain yang tidak dimasukkan dalam penelitian ini. Faktor lain yang memengaruhi hasil belajar diantaranya faktor endogen dan eksogen. Faktor endogen terdiri dari faktor fisik (kesehatan dan cacat tubuh) dan psikis (intelegensi atau kemampuan, perhatian dan minat, bakat, motivasi, kematangan, dan kepribadian) sedangkan faktor eksogen ini meliputi faktor keluarga, faktor sekolah, dan faktor lingkungan lain (Sobur, 2016). 
Disiplin belajar merujuk pada efisiensi waktu yang ditunjukkan dengan kemampuan siswa menyelesaikan tugas-tugas yang diberikan oleh guru dengan tepat waktu dan hasil yang baik. Adanya disiplin belajar yang terbentuk pada kepribadian siswa dapat meningkatkan produktivitas belajar. Sedangkan kemandirian belajar dilakukan atas dorongan internal dari individu tanpa bergantung pada orang lain untuk menguasai kompetensi guna mengatasi suatu masalah. Dengan memiliki kemandirian belajar, siswa dapat mengerjakan tugas-tugasnya dengan penuh percaya diri disertai rasa tanggungjawab yang tinggi dan mampu mengatasi masalah yang muncul pada dirinya. $\mathrm{D}$ isiplin dan kemandirian belajar secara bersama-sama menguntungkan dalam proses pembelajaran dengan penyelesaian tugas-tugas yang diberikan oleh guru dengan tepat waktu, tanpa bergantung pada orang lain, dan mengatasi masalah dengan pengendalian diri yang baik.

Hasil Penelitian ini sesuai dengan penelitian yang dilakukan oleh Puspitasari \& Sutriyono (2017) didapatkan nilai signifikan F Change adalah $0,032<0,05$, sehingga dapat disimpulkan bahwa ada hubungan yang signifikan antara kemandirian belajar dan kedisiplinan belajar secara bersama-sama dengan prestasi belajar matematika.

\section{SIMPULAN}

Hasil penelitian ini yaitu sebagai berikut. Pertama, terdapat pengaruh positif namun tidak signifikan antara disiplin belajar terhadap hasil belajar matematika $\left(\mathrm{t}_{\text {hitung }}=\right.$ $\left.0,977<t_{\text {tabel }}=1,652\right)$. Besar sumbangan efektif disiplin belajar terhadap hasil belajar matematika siswa kelas V SDN se-Kecamatan Klirong tahun ajaran 2019/2020 sebesar 2,09\%. Kedua, terdapat pengaruh antara kemandirian belajar dengan hasil belajar matematika ( $t_{\text {hitung }}=5,013>t_{\text {tabel }}=1,652$ ). Besar sumbangan efektif kemandirian belajar terhadap hasil belajar matematika siswa kelas V SDN seKecamatan Klirong tahun ajaran 2019/2020 sebesar 15,35. Ketiga, terdapat pengaruh/ hubungan antara disiplin dan kemandirian belajardengan hasil belajar matematika $\left(F_{\text {hitung }}=24,559>F_{\text {tabel }}=19,491\right.$ dan Sig. 0,000 $<0,05$. Besar besar sumbangan efektif disiplin dan kemandirian belajar terhadap hasil belajar matematika siswa kelas V SDN se-Kecamatan Klirong tahun ajaran $2019 / 2020$ yaitu $17,44 \%$. Persamaan regresi yang diperoleh yaitu $Y=-9,367+0,013 X 1+0,075 X 2$. Berdasarkan hasil penelitian tersebut maka saran kepada pendidik atau guru hendaknya memberikan penghargaan dan hukuman yang mendidik siswa untuk termotivasi dalam menjalankan disiplin belajar. Selain itu, sebagai pendidik hendaknya menerapkan proses pendidikan yang demokrasi seperti memberikan kesempatan siswa untuk berpendapat, dan memberikan kebebasan pada siswa untuk mencoba sehingga siswa lebih mandiri dalam belajar.

\section{DAFTAR PUSTAKA}

Alwi, I. (2015). Kriteria Empirik dalam Menentukan Ukuran Sampel pada Pengujian Hipotesis Statistika dan Analisis Butir. Jurnal Formatif, 2 (2), 140-148

Asrah, B., Novita, R., \& Fitriati. (2016). Korelasi Kedisiplinan Belajar di Rumah dengan Prestasi Belajar Matematika Siswa Sd Negeri 19 Banda Aceh. Numeracy: Jurnal IImiah Pendidikan Matematika, 3 (2), 44-51.

Aunurrahman. (2019). Belajar dan Pembelajaran. Bandung: Alfabeta.

Daryanto \& Darmiatun, S. (2013). Implementasi Pendidiksn Karakter di Sekolah. Yogyakarta: Gava Media

Desmita. (2017). Psikologi Perkembangan Peserta Didik. Bandung: PT Remaja Rosdakarya

Dewi, K. M. S., Suwatra, I. W., \& Suwarjana, M. (2019). Kontribusi Disiplin Belajar dan Motivasi Berprestasi Terhadap Hasil Belajar Matematika. Journal for Lesson and Learning Studies, 2 (1), 121-130.

Djamarah, S. B. (2015). Psikologi Belajar. Jakarta: Rineka Cipta

Elly, R. (2016). Hubungan Kedisiplinan Terhadap Hasil Belajar Siswa Kelas V di SD Negeri 10 Banda Aceh. Jurnal Pesona Dsar, 3(4), 43-53. 
Kompri. (2014). Manajemen Sekolah Teori dan Praktik. Bandung: Alfabeta Nurhayati, E. (2016). Psikologi Pendidikan Inovatif. Yogyakarta: Pustaka Pelajar Purwanto. (2012). Metode Penelitian Kuantitatif untuk Psikologi dan Pendidikan. Yogyakarta: Pustaka Pelajar.

Puspitasari, H. M. \& Sutriyono. (2017). Hubungan Kemandirian Belajar dan Kedisiplinan Belajar terhadap Prestasi Belajar Matematika. Jurnal Mitra Pendidikan (JMP Online). 1 (10). 1007-1020.

Rahartiwi, M. (2016). Hubungan Antara Kedisiplinan dengan Hasil Belajar Siswa Kelas V SD Gugus Srikandi Semarang Barat. Skripsi Tidak Dipublikasikan, Universitas Negeri Semarang, Semarang.

Rusni \& Agustan. (2018). Pengaruh Kedisiplinan Belajar Terhadap Hasil Belajar Matematika Siswa Di Sekolah Dasar. Jurnal Riset Pendidikan Dasar, 1 (1), 1 - 9.

Sa'diyah, R. (2017). Pentingnya Melatih Kemandirian Anak. KORDINAT, 16(1), 31-46.

Sardiman. (2018). Interaksi dan Motivasi Belajar Mengajar. Depok: PT RajaGrafindo Persada

Slameto. (2013). Belajar dan Faktor-Faktor yang Mempengaruhinya. Jakarta: PT. Rineka Cipta

Sobur, A. (2016). Psikologi Umum. Bandung: Pustaka Setia.

Susanto, A. (2016). Teori Belajar Dan Pembelajaran Di Sekolah Dasar. Jakarta: Prenadamedia Group.

Syahputra, D. (2017). Pengaruh Kemandirian Belajar dan Bimbingan Belajar Terhadap Kemampuan Memahami Jurnal, Penyesuaian pada Siswa SMA Melati Perbaungan. At-Tawasuh, 2 (2), 368-388.

Wahyudi. (2015). Panduan Pembelajaran Matematika Sekolah Dasar. Surakarta: UNS Press.

Winarsunu, T. (2017). Statistik dalam Penelitian Psikologi, dan Pendidikan. Malang: UMM Press.

Woi, M. F. \& Prihatni, Y. (2019). Hubungan Antara Kemandirian Belajar dengan Hasil Belajar Matematika. Teacher in Educational Research, 1 (1), 2019, 1-8 